\title{
Unusual scars in a young female patient
}

\section{J E Lai Cheong, S M Rajpara, R M Azurdia}

\section{Answers on $p$ e5}

\begin{abstract}
A 36 year old woman was seen in $\triangle$ the dermatology department - because of a mole on her back On examination, she had an $8 \mathrm{~mm}$ uniformly pigmented lesion with regular margin and texture on her midback, which clinically was a benign naevus. The skin was also soft and hyperextensible, with a velvety appearance (fig 1). She also had extensive scars on her legs, forehead, arms, and back (fig 2), which developed after a viral illness when she was 10 years old. She was being treated by the rheumatologist for joint subluxation. She had one daughter who was similarly affected.
\end{abstract}

\section{QUESTIONS}

- What other signs and symptoms would she present with?
- What could be the cause of scars across her back?

- What is the diagnosis?

Postgrad Med J 2005:81:e4

(http://www.postgradmedi.com/cgi/content/ full/81/957/e4).

doi: 10.1136/pgmi.2004.026419

\section{Authors' affiliations}

J E Lai Cheong, S M Rajpara, R M Azurdia, Department of Dermatology, Royal Liverpool and Broadgreen University Hospital NHS

Trust, Liverpool, UK

Correspondence to: Dr J E Lai Cheong, Department of Dermatology, Royal Liverpool and Broadgreen University Hospital NHS Trust, Thomas Drive, Liverpool L1 4 3LB, UK; jelai_cheong@hotmail.com

Submitted 3 July 2004

Accepted 3 August 2004

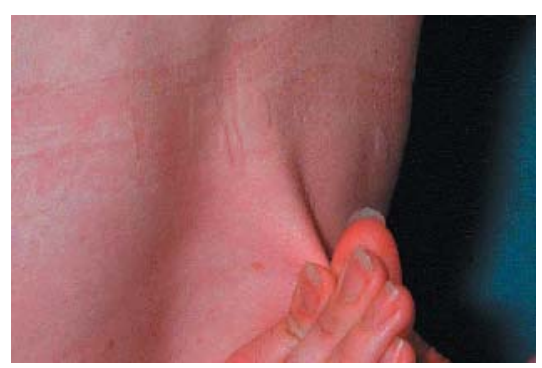

Figure 1 Soft and hyperextensible skin with a velvety appearance.

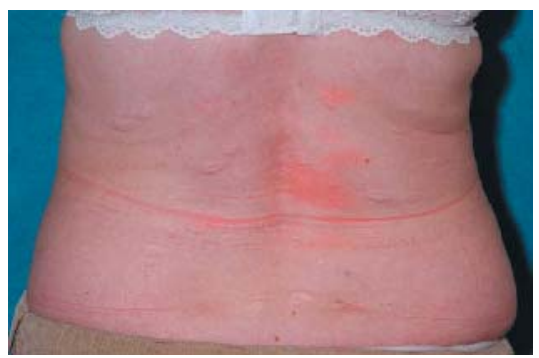

Figure 2 Multiple prominent scars across the back. 